\title{
Modal Auxiliary Verbs in Prescribed Malaysian English Textbooks
}

\author{
Jayakaran Mukundan (corresponding author) \\ Department of Language and Humanities Education \\ Faculty of Educational Studies \\ Universiti Putra Malaysia \\ 43400 UPM SERDANG, Selangor, Malaysia \\ Tel: 60-3-8946-6000 E-mail: jaya@educ.upm.edu.my \\ Laleh Khojasteh \\ Department of Language and Humanities Education \\ Faculty of Educational Studies \\ Universiti Putra Malaysia \\ 43400 UPM SERDANG, Selangor, Malaysia \\ E-mail: khojastehlaleh@yahoo.com
}

\begin{abstract}
The use of corpus-based findings in order to inform L2 teaching materials have been emphasized by many researchers owing to the fact that the studies of authentic texts have revealed some inconsistencies between the use of grammatical structures in corpora, and those found in language textbooks that are based purely on hunch. Therefore, by comparing a textbook corpus with the British National Corpus, this study attempts to shed light on the extent in which modal auxiliary verbs presented in the Malaysian prescribed textbooks are identical with those used by native speakers. The findings showed that there are discrepancies between English language textbooks and real language use. Findings from this study contribute to the improvement of pedagogical practices in the teaching of the modal system and provide a sense of familiarity with textbooks' content thus assisting educators in identifying the particular strengths and weaknesses in textbooks already in use.
\end{abstract}

Keywords: Modal auxiliary verbs, Prescribed textbooks, Corpus

\section{Introduction}

Modal auxiliary verbs have always formed an important part of the grammar and semantics of most languages, including English because they are not only auxiliaries in the prescriptive grammarian sense but they also appear to contribute to the semantics of communication (Manaf, 2007). Gueron and Lecarme (2008) support the fact that grammar devotes a lot of space to modality, and that modal sentences containing modal verbs occupy a unique position within this grammatical space.

Modals are said to be among the most problematic grammatical items (Palmer, 1974) for non-native students, including L2 Malaysian students, even though they share some common characteristics with 'primary auxiliaries'. Not only their forms, but also their semantic functions make it difficult for teachers when they attempt to impart knowledge on this extremely "messy and untidy" grammar structure to ESL students (Palmer, 1990).

In Malaysia, teaching of grammar has been emphasized to be incorporated into the four language skills of reading, writing, listening and speaking by Curriculum Development Centre of the Ministry of Education Malaysia and British English is currently the normative for Malaysian usage and the Malaysian schools. English is taught using prescribed textbooks which are selected to be used in Malaysia and they are bought using public funds and provided free to learners.

According to Nooreen and Arshad (2005), in Malaysia, one of the most fundamental language inputs received in the classroom by learners is a textbook. They contend that in the classroom context, students do not only enjoy the various benefits of the textbook as a teaching device that works alongside a teacher (Nooreen and Arshad, 2005), but also they use their textbooks as reference material. This enables them to revise and work on consolidation both inside and outside the classroom (Mukundan, 2004). However, it is worth mentioning that the prescribed textbooks used in Malaysian schools in their English language classes, as provided by the Textbook Bureau of the Ministry of Education Malaysia, were prepared through a process of material development that involved intuition and assumption (Mukundan, 2004). Since intuition (Mukundan, 2004) was used, then material writers have unwittingly presented their own assumptions on what is a relevant language and present their own preferred usage as the only correct or acceptable one. 
Corpus-based research has also proven that in many cases the ways in which words actually function are at odds with the intuition of teachers and textbook writers (Tognini-Bonelli, 2001). Thornbury (1999) also posits that although frequency information sourced from corpus databases has improved a lot, syllabus designers still tend to operate by hunch. Also Tongnini-Bonelli (2001) draws our attention to the fact that pedagogical grammars are often criticized for misrepresenting linguistic facts, and this mismatch according to Berry (1999, cited in Tognini-Bonelli, 2001) cannot be attributed to the process of pedagogic simplification, but to wrong input. Other studies lead to the same type of conclusion and shed some serious doubts on the way certain grammatical structures are generally taught (Romer, 1996; Kennedy, 1991 and many more).

The major aim of this textbook analysis, therefore, was to find out whether the use of modal auxiliary verbs in prescribed Malaysian English textbooks was an accurate representation of actual language use. More specifically, it sought to compare modal auxiliary verbs as represented in Malaysian English textbooks with their occurrence in reference corpus like the British National Corpus (here after BNC).

The leading questions were: "Is the form of modal auxiliary verbs taught in Form 1-3 prescribed Malaysian English textbooks identical to the modal forms used by native speakers?" and "Are the modal verb phrase structures in the English language textbooks of Form 1,2 and 3 identical to the modal verb phrase structures used by native speakers?"

\section{Literature Review}

Modals and modality have been defined in many ways by linguists and grammarians. Palmer (1990) sees modality as a grammatical system which its use can multiply our capability of expression. Lyons (1977) defines modality as something that concerns the speaker's opinion and attitude and for Mindt (1995) certain meanings can be expressed by modal auxiliary verbs that words on their own are barely adequate. However, the vagueness concerning modals semantic functions and lack of clear determination in their formal system has led to the unclear guidelines concerning the limits of defining modals.

According to Hoye (1997), in English, there are nine modal verbs that must certainly be included as the central modal auxiliary verbs and they are: will, would, can, could, may, might, shall, should and must. This list has been supported by Coates (1983), Quirk et al. (1985) and Biber et al. (2002). Among this list most of them express both core 'deontic' meanings such as 'obligation', 'intention' or permission (e.g. 'You must be home by 10pm'), or 'epistemic' meanings associated with truth conditions and assessment of degrees of certainty (e.g. 'You must be our new neighbour'). It is this semantic complexity which probably makes it difficult for L2 speaker to differentiate between 'deontic' meaning and 'epistemic' meaning of the same modal auxiliary verb (Kennedy, 2002). The semantic characteristic of modals makes the system unique and this uniqueness creates learning problems for ESL learners due to the lack of complete linguistic description (Thompson, 2002). In addition to these nine central modals there is a small group of 'marginal modals', ought to, need to, used to and need (Quirk et al. 1985) which can behave in some ways like modals and in other ways like main verbs. Furthermore, it is noted that there is also a small group of expressions known as 'semi-modals', which also function like modals namely: (had) better, (have) got to, be about to, be going to and be supposed to (Kennedy, 2002). Beyond the central group of nine words, these other groups of modals are not the focus of the present study.

\subsection{Corpus-based studies on Modal auxiliary verbs}

The importance of modal auxiliary verbs has been depicted in many corpus-based studies reviewed in the literature. While some have explored the distribution of modals (e.g. Mindt, 1995; Biber et al, 1999) others have focused on aspects of the semantic functions of modals (e.g. Quirk et al, 1985; Coates, 1983). Regional and historical variations in the use of modals have also been studied by some researchers (e.g. Collins, 1991; Biber et al. 1999). According to Kennedy (2002), verbs constitute about 20 percent of all the word tokens used in English, and in written texts, modal verbs typically constitute about 8 per cent of all verb forms.

Supporting the findings of Quirk et al.(1985:136), Kennedy (2002) described that 1,457,721 of the word tokens in the British National Corpus (1.45\%) are tagged as modals. Will, would, can, and could account for $72.7 \%$ of all the modal verb tokens, with the most frequent modal (will) accounting for almost $23 \%$ of all modal tokens in the corpus. The results further show that modals occur with much greater frequency in spoken texts than in written. In the spoken texts in the corpus there are 215,485 modals in 10 million words (Kennedy, 2002).

In Coates' 1983 study of modals in LOB (Lancaster-Oslo/Bergen Corpus) and the LLC (London-Lund Corpus), she estimated that spoken British English had 17.7 modals per thousand words, and written British English had 14.6 per thousand words. Biber et al (1998: 205-210) described how the distribution of the modals must with obligation 
meaning and should with necessity meaning has changed over time with increasing use of semi-modals such as have to and have got to.

Finally, a comparative analysis of BNC and a German textbook series was undertaken by Romer (1996) in order to see if there are differences between English grammar (modals) taught at schools and the English used by native speakers. Unlike Kennedy (2002), she only focused on 10-million-word spoken part of BNC with the rationalization that modal auxiliaries occur more frequently in spoken than in written English. Similarly though, will, would and can were identified as the most frequent modals followed by could in spoken English. The semantic variation of each modal auxiliary in BNC also investigated by Romer (1996) indicates that the dynamic meaning of can (ability) is the most frequent semantic function used followed by its epistemic (possibility) and deontic (permission) meanings. Like Kennedy (2002), Romer reveals that the highest percentages of negations were found with can and could, and that contracted forms (e.g., can't, 94.25\%) are in all cases much more frequent than full forms (e.g., cannot, 5.75\%). In revealing the results of $\mathrm{BNC}$ and textbook comparison, she considered modal auxiliaries frequencies, different meanings and co-occurrences and made it clear that there are huge discrepancies between the use of modal auxiliaries in authentic English and the English taught in German schools. Syntactically, there were incidences of overused cases of modals of will/'ll and can as well as underused cases of would/'d, could, should and might as compared to BNC. Semantically, the ability meaning of can and could have been overused in textbooks while in BNC could more frequently express a possibility than an ability. The most striking result though, according to Romer (1996), is that shall with its prediction meaning is never used in textbooks while in BNC this is one of the most important meanings. At the end, she suggests that more corpus-driven work needs to be done in order to enable pupils and teachers to learn and teach English which is more authentic and closer to that of native speakers.

\subsection{Modals and ESL learners}

As reported by many linguists, grammatical items have been one of the most challenging areas for ESL learners including Malaysian ESL learners (Celce-Murcia and Larsen-Freeman, 1983; Hughes and Heah, 1993; Holden et al., 1993; Gaudart, Hughes and Michael, 1996; Pillary and North, 1997; Hawanum, 2004). The correct use of modals, according to Hughes and Heah (1993), was always among one of the most problematic areas for Malaysian learners. Wong (1983: 136) also agrees with the fact that the modal auxiliary system of standard formal English in Malaysia is enormously complicated because the same modals sometimes are used to express different functions like that of probability, possibility and certainty, and of inclination, ability, permission and obligation. Rosli and Edwin (1989) in their study of students' errors in Form 4 students' composition found that verb forms and the verb aspects of modals are the most problematic. An investigation concerning Malaysian ESL learners' use of modals in two written tasks, which were obtained from EMAS Corpus was undertaken by Manaf (2007). It was found, firstly, that students were uncertain about which modals to use to express modality in their sentences which could be seen in their inaccuracy at the syntactic and semantic levels. Secondly, it was found they also had difficulty using modals with appropriate verb forms in a sentence. Manaf (2007) noted that there might be some inadequacies in the syllabus that could have led to the problems encountered by ESL students in Malaysia. In order to address the problematic grammatical items, she suggested reviewing the syllabus so that the contents of English language textbooks used in Malaysia would in future be in line with the recommended textbooks used by students.

In a similar study done by Bose (2005) in India, he relates students' difficulty with modal auxiliary verbs with the way these verbs are introduced to students. He stresses that it is also important to teach the modal item in a manner that will allow students to retrieve and use them well. In much the same way, corpus studies of modals (Holmes, 1988; Hyland, 1998; McEnery \& Kifle, 2002) all conclude that some EAP textbooks and style guides should be blamed for presenting misleading explanations at one hand and failing to teach the full repertoire of modal language and a number of items learners would find most useful on the other hand. In a study of 22 textbooks, Hyland (1994) reaches the following conclusions:

"For the most part, modal expressions are simply introduced without system or comment and are summarily dealt with in a single exercise which fails to emphasise either their function or importance. Generally, the range of modal verbs addressed and the information provided on their use is inadequate." (p. 247)

With reference to the social functions of modals, Thornbury (1999) believes problems using modals might lead to difficulty in conveying interpersonal meaning and in fine-tuning the meaning we wish to express. That indeed might be the reason why many ESL/EFL students do not recognize that they sometimes sound unpleasant, for example, when they request something in given social circumstances (Celce-Murcia and Larsen-Freeman, 1983). Consequently, it is important to note that in the case of social interaction, the students should be taught the relevant features of the situation since this teaches them how to select the appropriate modal auxiliary in any given interaction which in the case of failure communication might be hindered (Thornbury, 1999). 
Not having enough exposure to modal auxiliary verbs in textbooks for Malaysian learners may pose problems in understanding them and may also contribute to students' reported inability with using them in sentences. Hence, teachers of ESL/EFL should be aware of the dynamics of the problem to enable them to teach this grammatical item to their students more effectively. As Kennedy (1991) noted, the traditional emphasis on the grammatical paradigm has to be revisited in favor of a more syntagmatic approach to use in context.

\section{Methodology}

The development of computer-based language corpora has, in recent years, facilitated a great deal of fascinating research. These data bases consist of thousands of texts containing millions of words in context. In addition to enabling researchers to do frequency counts, they also reveal fascinating patterns in language. For example, concordancing programs enable researchers to explore the contexts in which particular words and phrases occur, and the other words with which they co-occur. This study harnesses a similarly analytical approach to investigate whether or not there may be a discrepancy between the English language represented in Malaysian secondary school textbooks and that which is needed and used in real life communication. However, it is worth mentioning that the methodological base of this corpus-based study does not only cover the field of corpus linguistics but also involves content analysis and discourse analysis in the process of analysing the lexical and grammatical relationships of modal auxiliary verbs in the text.

\subsection{Population and Sampling}

For the purpose of this study, the population for the English language corpus is defined as the prescribed English language textbooks used by lower secondary level students of Form 1, Form 2 and Form 3. This corpus consists of 153,889 running words which have been chosen in order to identify the frequency occurrences of nine central modals and their verb phrase structures.

This textbook-based corpus is compared with the BNC to investigate the frequency rank or order of all central modals in each. The BNC (accessible from, http://www.natc orp.ox.ac.uk/) is a 100 million word collection of written and spoken language from a wide range of sources. The larger portion of written language comprise of 90 million words of written English prose from nine genres whereas the remaining 10 million words of spoken English samples are from participants belonging to 38 geographical locations in Great Britain. For the purpose of this study both spoken and written texts were used.

\subsection{Instrumentation: WordSmith Tools 4}

WordSmith Tools was designed by Mike Scott $(1996,1997,1999)$ and is considered as a very convenient tool, not only for students but also teachers who may use it for textbook adaptation (Scott, 2001). WordSmith tools provides instantaneous displays of word frequency lists; concordances, which show all the uses of a given word in its contexts; and lists of keywords (Ghadessy, Henry and Roseberry, 2001). For the purpose of this study only the WordList and Concord tools are used. With the help of the WordList tool of the computer software, the researcher is able to identify the frequency occurrence of the chosen modal auxiliary verb. Then, after consideration of each modal verb phrase structure in turn, concordance entries were created with the assistance of the Concord tool.

\section{Results and Discussion}

4.1Is the English taught in Form 1-3 prescribed Malaysian English textbooks identical to the English which is used by native speakers?

There are six modals which are required to be taught in KBSM syllabus for lower secondary students namely: must, will, should, can, may and might. It is important to note that although could is introduced and taught to students at primary 5 and is emphasized again at primary 6, there isn't any evidence of reinforcing this modal auxiliary with the students at lower and upper secondary level. Furthermore, would and shall is not explicitly taught at either primary or lower and upper secondary level. The frequency of could, would and shall, however, is investigated in this study in order to see how many times these modals are presented to students throughout the texts during three years of study. The modals which have been taught implicitly in each of the textbooks for Form 1, 2 and 3 have been highlighted in Table 1 in order to differentiate between other modals which are only presented in the textbooks but not directly taught. As it can be seen in Table 1 and Figure 1 the modal auxiliary verbs (excluding their negative forms) found in the three English textbooks of lower secondary level are presented in a descending order: can, will, should, would, must, may, could, might and shall. It is interesting to note that except for modals might and shall which have an increased frequency in textbooks from Form 1 to Form 3, the rest of the modals have dwindling frequency occurrences throughout the textbooks. Modals like may and must have an upward trend from Form 1 to Form 2 but a lower frequency occurrence can be seen in the Form 3 textbook. In the case of can, will, should, could and would, the arrows in table 1 shows that they begin with a higher frequency in Form 1, shows a 
lower frequency occurrence in Form 2 and regain their frequency occurrences in Form 3. The modal should has appeared in the Form 1 textbook 94 times, however its frequency dropped to 35 in Form 2 and then tripled to approximately 92 in the Form 3 textbook. In the same fashion could has appeared 35 times in the Form 1 textbook, dropped its frequency occurrence to 14 times in the Form 2 textbook and regained its frequency occurrence in Form 3 with 34 times. It can be interpreted from the table that the modal shall is not presented consistently throughout the textbooks. This modal appears only 4 times in the Form 1 textbook, 5 times in the Form 2 textbook and finally 8 times in the Form 3 textbook. Similarly, might has only appeared 4 times in the Form 1 textbook.

The order of modal auxiliaries ranked by frequency as they are presented in the BNC (accessible from Word Frequencies in Written and Spoken English (WFWSE) in http://ucrel.lancs.au.uk/bncfreq/flists.html) is quite different to that of modals in the Form 1, 2 and 3 textbooks (Table 2). In the BNC, for instance will, would, can and could are considered the most frequent modals (they account for $72.7 \%$ of all modal tokens) according to Kennedy (2002). However, as it can be seen in the table, could in the textbook corpus has lost its place and gone to the 7th place, while should has taken its position in the third place and will, would and can are among the top four most frequent modals in the textbooks. Will is the most frequent modal in BNC while it reaches second in the textbook corpus. The modal must appears before modal could in the textbook corpus having modal may in between, while in BNC not only the modal could appears before must but also there are two other modals (may and should) in between.

This study has revealed that for almost all of the modal auxiliaries, there is a discrepancy between frequency order in the textbook corpus and the BNC. The reason for that is unknown but it might be because of the content of the BNC which includes various authentic spoken and written texts while our textbook corpus only contains prescribed pedagogical texts or it may signal a deficiency in the preparation of the textbooks. It is worth mentioning, that in the case of the top four most frequent modals, from a distributional perspective, Quirk et al. (1985) in the Brown LOB and SEU corpora and Coates (1983) in LLC and LOB corpora of spoken and written texts also came to the same conclusion that modals will, would, can and could in a descending order are considered as the most frequent modals. Consequently, it is both a surprise and a concern to see that the modal could is neither among the top four most frequent modals in the textbook corpus nor taught to lower secondary learners, although it should be recycled in language instruction more often. Similarly, would is among the top four modals in the textbook corpus but it is not taught explicitly in any of the textbooks.

4.2 Are the modal verb phrase structures in the English language textbooks of Form 1, 2 and 3 identical to the modal verb phrase structures used by native speakers?

At a formal level of analysis, the modal verbs might seem to be used in quite a simple canonical paradigm followed by the bare infinitive. (e.g. Fred and Sue will/ would/ can/ etc go to the movies). However, there are other forms that might be presented in one verb phrase but not necessarily in all verb phrases. According to Greenbaum (1996: 246-7) "the auxiliaries appear in a set sequence: modal - perfect have - progressive be - passive be - main verb". Table 3 shows the nine verb phrase structures in which modal verbs can occur. As Biber et al (1999) has demonstrated, some modals are most common in some constructions while the same modals are rarely used in other constructions. For instance, can, could, should and must are fairly common in passive constructions while may, might, should and must are the most frequently used modals with perfect aspect. This picture has been supported by Kennedy (2002) in BNC, Mindt (1995) and Biber et al (1999).

Table 4 contains an analysis of the distribution of the nine modal verb phrase structures in the textbook corpus, plus the none of the above item $(\mathrm{N})$ which includes interrogatives and modals that end the sentences as well as those which have been used in exercises and does not have a sentence format. In the textbooks they have been used in exercises such as fill in the blanks, jumbled sentences and multiple choice tasks (see (1), (2) and (3) for examples from textbook corpus).

(1) Then, write out the sentences using 'must' or 'must not'.

(2) You must ... good example.

(3) Give suitable responses to these sentences using 'must' or 'must not'. Students are sometimes rude to teachers. Students must....

The modal + infinitive structure (structure 2 ) is the most used structure for almost all modals in Form 1, 2 and 3. Out of 226 items, structure 2 occurs for modal can 132 times in the Form 1 textbook. In the Form 2 textbook almost half of the occasions in which the modal can is used it follows structure 2, and in the Form 3 textbook structure 2 contributes to a high proportion of modal can usage. A similar trend is found for most other modals. The exceptions are the modal could, which only appears 4 times used in the central modal style in Form 2, while it appears almost 
10 times as a "none of the above" item; and might which has frequency occurrences in Form 1, 2 and 3 textbooks of 4,8 and 13 respectively. There is also a zero occurrence of structure 2 for modal shall in the Form 1 and 2 textbooks while this structure occurs 5 times in the Form 3 textbook.

Considering passive constructions (structure 3,7 and 9), except for the modal can which has been repeated adequately throughout the Form 1 to 3 textbooks, there are not enough frequency occurrences for other modals. For example, the modal will with a passive aspect with be has frequency occurrences for the Form 1, 2 and 3 textbooks of 5,6 and 7 respectively. Structure 3 is used much less for modal should $(7,4,4)$, must $(1,4,7)$ and could $(3,0,4)$ although it is believed that these three modals are fairly common in passive constructions used by native speakers. Might and shall have not been used even once in structure 3.

Structure 1 (modal alone) has only occurred once in the Form 2 textbook for modals can and will, and should and would have also appeared once in structure 1 in the Form 1 and Form 3 textbooks. Considering the fact that Kennedy (2002) considers this structure one of the structures that should definitely be considered in language pedagogy, we can conclude that there is not enough exposure to this structure in the textbook corpus (see (4) and (5) for examples from textbook corpus).

(4) Is there anything I can do to help? Yes, you can.

(5) Will you be here by 10 ? I will.

Modal with a perfect aspect, is supposed to be more common for modals may, might, should, would and must (Biber et al. 1999). Except for modal would in the Form 3 textbook (10 times) there is not enough incidence of frequency occurrence of this structure in the Form 1 and Form 2 textbooks. For other modals such as can, will and shall the frequency occurrence is zero in all three textbooks. Should with a perfect aspect only occurs once in the Form 1 and twice in the Form 3 textbook. May and might have only appeared twice in Form 3 textbook (see (6), (7) and (8) for examples from textbook corpus).

(6) She should have bought (this/these) instead.

(7) He may have thought of you as his father.

(8) ... and inquire what harm you may have done.

Other modal structures $(6,7,8$ and 9$)$ are not really common in the textbook corpus which can be considered a quite normal reflection of common English usage as supported by Kennedy (2002), except for structure 7 which occurred once in the Form 3 textbook for the modal could (see (9) for example from the textbook).

(9) Son could have been killed.

\section{Conclusion}

The findings of this study have shown several valuable insights. Firstly, the frequency and ranked order of modal auxiliary verbs found in the English language textbooks used in Form 1, 2 and 3 in Malaysian Secondary Schools has been revealed. The data shows how many times modals are used in the textbooks and that either directly or indirectly students have been exposed to these modal auxiliaries in varying degrees. This is significant in itself because learning the use of modal auxiliaries is influenced by the frequency of occurrence of individual words or phrases (Tognini-Bonelli, 2001). In the ESL environment, students need to be exposed to the language as much as possible to gain sufficient input and exposure. For example rare occurrences of might and shall (less than five times) may not be enough to lead learners to notice and acquire these forms. Even in vocabulary studies, repetition of words is very important to ensure acquisition of new vocabulary (Mukundan \& Anealka, 2007). One kind of repetition that is important is repetition of encounters with a word. It has been estimated that, when reading, words stand a good chance of being remembered if they have been met at least seven times over spaced intervals (Thornbury, 2002). According to Celce-Murcia and Larsen-Freeman (1983) it makes sense to recycle various aspects of the target structures over a period of time: revisit old structures, elaborate on them, and use them for points of contrast as new grammatical distinctions are introduced.

Secondly, this study has revealed that for certain modal auxiliaries, there is a discrepancy between modal frequency order in the textbook corpus and the BNC showing how textbooks neglect important information on the use of this structure in real language. Although Howarth (1998) and Widdowson (1990) questioned the pedagogical usefulness of frequency lists generated by corpora because they believe frequency does not indicate any significance, especially in the area of problematic processing of language, Romer (1996:186) claims that frequencies are the keys to lead us to words or structures which are central in a language. Without them, he notes, it is difficult to decide what should be included in teaching materials and specifically in the case of modal auxiliary verbs, which modals for example should be prioritized over others in EFL/ESL teaching. The content and the sequencing of the curriculum and the 
weight given to different items in classroom activities can benefit from drawing their insights from corpus evidence (Togini-Bonelli, 2001). Kennedy (2002), among others, points to the need to concentrate initial teaching on high frequency items and to grade vocabulary and structures accordingly and Conrad \& Biber (2005) emphasizes on the importance of the frequency information for teachers because it helps them to decide which items to emphasize, for example, to provide low-level students practice with the items they are most likely to hear outside class.

This study has assumed that, in the Malaysian context, the aim of language instruction is to move learners towards a standardised form of language usage and communicative competence. The parameters of such a standard are, of course, and will always be open to debate. It is noted too, that some educators decry learner dependence on textbooks, in favour of teacher-generated materials that more closely meet individual learner needs. The study findings give support to suggestions that teachers include a broad range of authentic texts among learning materials used in teaching programmes. It has to be noted also, that as in other countries, with deference to the idealised "native speaker competency", the development of a unique local form of common English usage is an overlapping phenomena that adds more dynamic tension to the need for effective teaching and teaching materials.

We should bear in mind that corpus-based findings on modal auxiliaries can be integrated into a form-focused model of instruction in order to inform L2 textbook descriptions and prevent them from neglecting important information on the use of this structure in real language (Barbieri \& Eckhardt, 2007). In this survey, modal usage in textbooks was found to contrast with real language usage. For example, could, which has been identified as one of the most frequent modals in at least four major corpora, is not even taught to students at lower secondary level. Although Thornbury (2004) has indicated that the most frequently occurring items are not always the most useful ones in terms of teachability, and that they may be better delayed until relatively advanced levels, in the case of this textbook corpus the modals could and would are both not taught at higher secondary levels too. Barbieri \& Eckhardt (2007) indicate that despite more than two decades of language teaching aimed at fostering natural spoken interaction and written language, instructional textbooks still neglect important and frequent features of real language users. This has been supported by other linguists such as Carter and McCarthy (1995), Harwood (2005) and Hyland (1994).

Finally, there are very great differences in the relative frequency of use of the nine verb phrase structures in which modals can occur. Structure 2 in Table 4 (modal followed by the bare infinitive) is overwhelmingly dominant for almost all modals in the textbook corpus. However, the survey result reveals that lower secondary learners are not really exposed to other verb structures, particularly structures with passive, progressive and perfect aspects. Perhaps that would be one of the reasons why Rosli and Edwin (1989) in their study of errors in Form 4 student compositions found that verb forms and the verb aspects of modals are the most problematic for Malaysian learners. According to Kennedy (2002) the above mentioned structures including structure 1 (modal alone) should have a high priority in language pedagogy.

\section{Suggestions for the improvement of teaching materials}

The use of corpus-based findings in order to inform L2 teaching materials has been emphasized by many researchers (see, for example, Biber and Reppen, 2002; Conrad, 1999; 2000; Carter and McCarthy, 1995; Holmes, 1988; Harwood, 2005). It is through corpus-based studies that the "scope" of certain features can be investigated (Hulstijn, 1995). According to Barbieri \& Eckhardt (2007) "corpus-based analysis is an ideal tool to re-evaluate the order of presentation of linguistic features in textbooks, and to make principled decisions about what to prioritize in textbook presentations".

With regards to modal auxiliary verbs, the results of this corpus-based study tend to provide a sense of familiarity with three prescribed textbooks' content, thus assisting educators in identifying the particular strengths and weaknesses in textbooks already in use and helping them to overcome the discrepancies in order to achieve a higher degree of authenticity in textbook corpus. This level of awareness of modal auxiliary verbs and familiarity with them would also go a long way in ultimately assisting teachers with making optimum use of a textbook's strong points, recognizing the shortcomings of certain exercises, tasks, and entire texts. Most importantly, research based on the comparison of textbook corpus and reference corpora or real-language corpora has resulted in the development of more effective materials (Gabrielatos, 2005). For example, as the survey results reveal, since there is not any implicit teaching of modals would, could and shall in the entire lower secondary level as well as should which is only taught in the Form 1 textbook and not in Form 2 and 3, it is important for teachers to supplement the textbook and adapt their teaching materials. This has to be considered whilst writing their lesson plans. Also, as research has shown, when a structure is introduced to students it is important for that structure to be taught repetitively in order to enhance students understanding before it fades away from their memories. According to 
Thompson (2002) modals need to be understood well before their use can be imparted in an acceptable form. It is then that students are able to accept both their complexity and ambiguity.

A couple of changes concerning the use of modal verbs might be helpful to make the English that is taught more natural and native like. First of all, we would suggest changing the order in which the modals are introduced from can $\rightarrow$ will $\rightarrow$ should $\rightarrow$ would $\rightarrow$ must $\rightarrow$ may $\rightarrow$ could $\rightarrow$ might $\rightarrow$ shall to will $\rightarrow$ would $\rightarrow$ can $\rightarrow$ could $\rightarrow$ may $\rightarrow$ should $\rightarrow$ must $\rightarrow$ might $\rightarrow$ shall which is based on empirical corpus findings. Kennedy (1991) among others points to the need to concentrate initial teaching on high frequency items and to grade structures accordingly. According to Romer (1996) from a communicative point of view more frequent verbs can be considered more important ones and should be introduced at earlier stages in the learning process than less frequent ones. Secondly, it is important, if we want to enable pupils to communicate successfully, not to leave out some of the modal forms without teaching them explicitly. For example in the case of modal shall it is important to note that although corpus-driven studies report a rare frequency of this modal (see Biber et al., 2002), this should not necessarily mean we should neglect it. According to Romer (1996) the prediction meaning of shall is among one of the most important meanings (with $31 \%$ ) in BNC data evaluation of Spoken English. According to Conrad (2000) rare grammatical features can have important discourse functions in particular registers hence it is vital that decisions about pedagogy consult corpus linguistics by "taking into account functional descriptions and frequency information as well as analyses of students' needs".

As most of the modals were found to be used too frequently in the form of modal + infinitive in the Malaysian high school English Form 1, 2 and 3 textbooks, this overuse ought to be avoided if possible. This is not to say that they should be excluded, but it is important for learners to be exposed to various modal phrase structures in order to be able to communicate effectively in different functions. In other words, any emphasis given to teaching the modal followed by infinitive form shouldn't be at the expense of other important features which students need to be exposed to as well.

\section{References}

Biber, D., Conrad, S., and Reppen, R. (1998). Corpus Linguistics. Cambridge: Cambridge University Press.

Biber, D., Johansson, S., Leech, G., Conrad, S. and Finegan, E. (1999). Longman Grammar of Spoken and written English. Harlow: Pearson Education.

Biber, D. and Reppen, R. (2002).What does frequency have to do with grammar teaching? Studies in Second Language Acquisition, 24, 199-208.

Biber, D., Conrad, S. \& Leech, G. (2002). Longman students grammar of spoken and written English. Essex: Pearson Education.

Barbieri, F., \& Eckhardt, S. (2007). Applying corpus-based findings to form-focused instruction: The case of reported speech. Language Teaching Research, 11, 319-346.

British National Corpus (BNC). [Online] Available: http://www.natc orp.ox.ac.uk/ (April 1, 2009)

Bose, A. C. (2005). The problems in learning modal auxiliary verbs in English at high school level. Language in India. Retrieved 3/01/2010. http://www.languageinindia.com/nov2005/chandrabose1.html

Carter, R. and McCarthy, M. (1995). Grammar and the spoken language. Applied Linguistics, 16, 141-58.

Celce-Murcia, M. and Larsen-Freeman, D. (1983). The Grammar book: an ESL/EFL teacher's course. $2^{\text {nd }}$ ed. Boston: Heinle and Heinle.

Coates, J. (1983). The semantics of the modal auxiliaries. London: Croom Helm.

Collins, P. (1991). The modals of obligation and necessity in Australian English. In Aijmer \& Altenberg (Eds.), English Corpus Linguistics. London: Longman

Collins, P. (2009). Modals and Quasi-Modals in English. Amsterdam: Rodopi.

Conrad, S. \& Biber, D. (2005). The frequency and use of lexical bundles in conversation and academic prose. In W. Teubert and M. Mahlberg (Eds), The Corpus Approach to Lexicography, (pp.56-71). Internationales Jahrbuch für Lexikographie, 20.

Conrad, S. (1999): The importance of corpus-based research for language teachers. System, 27, 1-18.

Conrad, S. (2000): Will corpus linguistics revolutionize grammar teaching in the 21 st century? TESOL Quarterly, 34 , $548-60$.

Guéron, J. \& Lecarme, J. (Eds), Time and Modality: Studies in Natural Language and Linguistic 
Theory. Springer (Dordrecht).

Gabrielatos, C. (2005). Corpora and language teaching: Just a fling, or wedding bells? TESL-EJ, 8, 1-37.

Gaudart, H., Hughes, R. and Michael, J. (1996). Towards better English Grammar. Shah Alam: Fajar Bakti.

Ghadessy, M., Henry, A. \& Roseberry, R. (Eds) (2001). Small corpus studies and ELT. Amsterdam/ Philadelphia: John Benjamons Co.

Greenbaum, S. (1996). The Oxford English Grammar. Oxford: Oxford University Press.

Harwood, N. (2005). What do we want EAP teaching materials for? Journal of English for Academic Purposes, 4, $149-161$.

Hawanum Hussein (2004). Using simple poems to teach grammar. The internet TESL Journal. 10 (5).

Holden, A., and Singh, J. (1993). Remedial English grammar and usage. Shah Alam: Fajar Bakti.

Holmes, J. (1988). Doubt and certainty in ESL textbooks. Applied Linguistics, 9, 21-44.

Hoye, L. (1997). Adverbs and modality in English. London: Longman.

Howarth, P. (1998). Phraseology and second language proficiency. Applied linguistics, 19, 24-44.

Hughes, R. and Heah, C. (1993). Common errors in English: grammar exercises for Malaysians. $2^{\text {nd }}$.ed. Shah Alam: Fajar Bakti.

Hulstijn, J.H., 1995: Not all grammar rules are equal: giving grammar instruction its proper place in foreign language teaching. In R. Schmidt (Ed). Attention and awareness in foreign language learning (Technical Report No.6), (pp. 359-386). Honolulu: University of Hawaii Second Language Teaching and Curriculum Center,

Hyland K, 1994. Hedging in academic writing and EAP textbooks. English for Specific Purposes, 13(3).

Hyland, K. (1998). Hedging in scientific research articles. Amsterdam/ Netherlands: John Benjamins B.V.

Kennedy, G. (1991). Between and through: the Company they keep and the functions they serve. In Celce-Murcia, M. \& Larsen-Freeman, D (Eds.), The Grammar Book: An ESL/EFL Teacher's Course (2 ${ }^{\text {nd }}$ edition). (pp. 401-404). USA: Heinle \& Heinle Publishers.

Kennedy, G. (2002). Variation in the distribution of modal verbs in the British National Corpus. In Reppen, R., Fitzmaurice, S. M, \& Biber, D (Eds.), Using corpora to explore linguistic variation (pp. 74-90). Amsterdam/ Philadelphia: John Benjamins Publishing Co.

Lyons, J. (1977). Semantics. Vol 2. Cambridge: Cambridge University.

McEnery T. \& Kifle N.A. (2002). Epistemic modality in argumentative essays of second-language writers. In Flowerdew J. (Ed.) Academic Discourse (pp. 182-215). London: Longman.

Mindt, D. (1995). An Empirical Grammar of the English Verb: Modal Verbs. Berlin: Cornelsen.

Mukundan, J. (2004). Making Textbook Evaluation Meaningful. In Mukundan, J. et al. (Eds.), ELT Matters 2: Developments in English Language Learning and Teaching (pp. 105-113). Serdang: Universiti Putra Malaysia Press.

Mukundan, J. \& Anealka, A. H. (2007). A forensic study of vocabulary load and distribution in five Malaysian Secondary School Textbooks (Forms 1-5). Pertanika Journal of Social Science and Humanities. 15, 59-74.

Murugesan, V. (2003). Malaysia Promotes Excellence in English. Retrieved on April 7, 2009. Available on http://www.eltcm.org/eltc/.

Nooreen, N \& Arshad Abd. S. (2005). Examining the Importance of EST and ESL Textbooks and Materials: Objectives, Content and Form. English for Specific Purposes World. [Online] Available: http://www.esp-world.info/Articles_9/textbooks.htm (December 4, 2009).

Palmer, F.R. (1974). The English verb. London: Longman.

Palmer, F. R. (1990). Modality and the English modals. London: Longman, (Chapter 2).

Pillary, H. and North, S. (1997). Tied to the Topic: integrating grammar and skills in KBSM. The English Teacher, 26.

Quirk, R., Greenbaum, S., Leech, G., and Svartvik, J. (1985). A comprehensive grammar of the English language. London: Harlow.

Romer, U. (1996). A corpus-driven approach to modal auxiliaries and their didactics. In Sinclar (Ed.), How to Use Corpora in Language Teaching (pp.185-199). Amsterdam/Philadelphia: John Benjamins.

Rosli,T. \& Malachi, E. (1989). Error analysis of form four English compositions. The English Teacher. 28. 
Scott, M. (1996, 1997, 1999). Versions (1.0, 2.0, 3.0, 4.0) WordSmith Tolls. Oxford: Oxford University Press.

Scott, M. (2001). Comparing corpora and identifying key words, collocations and frequency distributions through WordSmith Tolls suite of computer programs. In Ghadessy, M., Henry, A., \& Roseberry, R. L. (Eds.), Small Corpus Studies and ELT (pp. 47-67). Amsterdam/ Philadelphia: John Benjamins Publishing Co.

Thornbury, S. (1999). How to Teach Grammar. England: Pearson Education.

Thompson, M. (2002). Modals in English language teaching. [Online] Available:http://www.telusplanet.net/linguisticsissues/modalsinteaching.html (21 January, 2010)

Tognini-Bonelli, E. (2001). Corpus linguistics at work. Philadelphia: John Benjamins.

Wong, I. (1983). Simplification features in the structure of colloquial Malaysian English. Singapore: Singapore University. 125-149.

Widdowson, H. G. (1990). Aspects of language teaching. Oxford: Oxford University Press.

Table 1. Distributions of Central Modals in Form One, Two and Three textbooks

\begin{tabular}{|c|c|c|c|c|c|}
\hline & Central Modals & Total & F1 & F2 & F3 \\
\hline 1 & Can & 675 & 235 & 203 & 237 \\
\hline 2 & Will/'ll & 474 & 166 & $\times \sqrt{53}$ & 158 \\
\hline 3 & Should & 221 & 94 & 35 & 92 \\
\hline 4 & Would/'d & 183 & 66 & 46 & $7 \mathbf{Y}$ \\
\hline 5 & Must & 159 & 44 & $6 *$ & 51 \\
\hline 6 & May & 148 & 35 & S9 & 54 \\
\hline 7 & Could & 83 & 35 & $x 4$ & 34 \\
\hline 8 & Might & 44 & 4 & 10 & $2 \star$ \\
\hline 9 & Shall & 17 & 4 & $\bar{B}$ & 8 \\
\hline
\end{tabular}

Table 2. Comparisons of central Modals order in the BNC and in the English Language textbooks of Form 1, 2 and 3

\begin{tabular}{|c|c|c|}
\hline & Modal auxiliaries in the BNC & Modal auxiliaries in the textbook \\
\hline 1 & will & can \\
\hline 2 & would & will \\
\hline 3 & can & should \\
\hline 4 & could & would \\
\hline 5 & may & must \\
\hline 6 & should & may \\
\hline 7 & must & could \\
\hline 8 & might & might \\
\hline 9 & shall & shall \\
\hline
\end{tabular}

Table 3. Modal verb phrase structures

\begin{tabular}{|l|l|l|}
\hline & Structure & Example \\
\hline S1 & Modal alone & (Who will go?) I will. \\
\hline S2 & Modal + infinitive & Sam can swim./ She must be hungry. \\
\hline S3 & Modal + be + past participle & It should be replaced. \\
\hline S4 & Modal + be + present participle & They will be arriving soon. \\
\hline S5 & Modal + have + past participle & He might have done it. \\
\hline S6 & $\begin{array}{l}\text { Modal + be + being + past participle } \\
\text { (or adjective) }\end{array}$ & $\begin{array}{l}\text { It } \text { might } \text { be being done tomorrow./ He could } \text { be being } \\
\text { awkward. }\end{array}$ \\
\hline S7 & Modal + have + been + past participle & It should have been fixed. \\
\hline S8 & Modal + have + been + present participle & He must have been lying. \\
\hline S9 & $\begin{array}{l}\text { Modal + have + been + being + past } \\
\text { participle } \\
\text { (or adjective) }\end{array}$ & $\begin{array}{l}\text { He } \text { might have been being blackmailed./ They } \text { must have } \\
\text { been being careless. }\end{array}$ \\
\hline
\end{tabular}


Table 4. Modal verb phrase structures in textbook corpus

\begin{tabular}{|c|c|c|c|c|c|c|c|c|c|c|c|c|c|c|c|c|c|}
\hline & \multicolumn{4}{|c|}{ Can } & \multicolumn{3}{c|}{ Will } & \multicolumn{3}{c|}{ Should } & \multicolumn{3}{c|}{ Would } & \multicolumn{3}{c|}{ Could } \\
& F1 & F2 & F3 & F1 & F2 & F3 & \multicolumn{2}{|c|}{ F1 } & F2 & F3 & F1 & F2 & F3 & F1 & F2 & F3 \\
\hline S1 & - & 1 & - & - & 1 & 1 & 1 & - & - & - & - & 1 & - & - & - \\
\hline S2 & 132 & 102 & 155 & 97 & 106 & 122 & 30 & 20 & 70 & 24 & 17 & 29 & 19 & 4 & 12 \\
\hline S3 & 19 & 25 & 14 & 5 & 6 & 7 & 7 & 4 & 4 & - & - & 2 & 3 & - & 1 \\
\hline S4 & 1 & - & - & 6 & 3 & 1 & 1 & - & - & - & 1 & 1 & - & - & - \\
\hline S5 & - & - & - & - & - & - & 1 & - & 2 & 1 & 2 & 10 & - & - & - \\
\hline S6 & - & - & - & - & - & - & - & - & - & - & - & - & - & - & - \\
\hline S7 & - & - & - & - & - & - & - & - & - & - & - & - & - & - & 1 \\
\hline S8 & - & - & - & - & - & - & - & - & - & - & - & - & - & - & - \\
\hline S9 & - & - & - & - & - & - & - & - & - & - & - & - & - & - & - \\
\hline N & 83 & 81 & 68 & 58 & 38 & 25 & 54 & 11 & 16 & 41 & 28 & 28 & 13 & 10 & 20 \\
\hline
\end{tabular}

Table 4. Continued Modal verb phrase structures in textbook corpus

\begin{tabular}{|c|c|c|c|c|c|c|c|c|c|c|c|c|c|}
\hline & \multicolumn{4}{|c|}{ May } & \multicolumn{4}{c|}{ Must } & \multicolumn{3}{c|}{ Might } & \multicolumn{3}{c|}{ Shall } \\
& F1 & F2 & F3 & F1 & F2 & F3 & F1 & F2 & F3 & F1 & F2 & F3 \\
\hline S1 & - & - & - & - & - & - & - & - & - & - & - & - \\
\hline S2 & 27 & 36 & 25 & 9 & 34 & 24 & 4 & 8 & 13 & - & - & 5 \\
\hline S3 & 4 & 1 & 2 & 1 & 4 & 7 & - & - & - & - & - & 1 \\
\hline S4 & 1 & - & - & 6 & 3 & 1 & 1 & - & - & - & 1 & 1 \\
\hline S5 & - & - & 2 & - & 1 & 2 & - & - & 2 & - & - & - \\
\hline S6 & - & - & - & - & - & - & - & - & - & - & - & \\
\hline S7 & - & - & - & - & - & - & - & - & - & - & - & - \\
\hline S8 & - & - & - & - & - & - & - & - & - & - & - & - \\
\hline S9 & - & - & - & - & - & - & - & - & - & - & - & - \\
\hline N & 10 & 21 & 25 & 24 & 31 & 28 & - & 11 & 6 & 4 & 5 & 2 \\
\hline
\end{tabular}

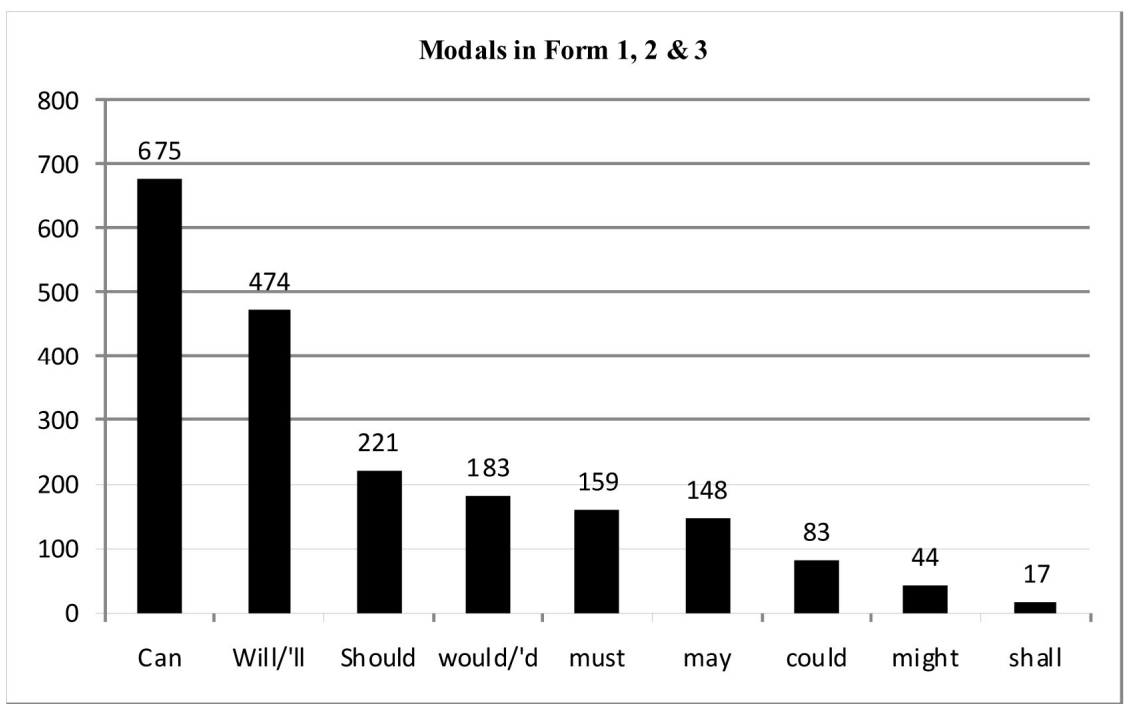

Figure 1. Frequency of modals in Form 1, 2 and 3 English textbooks 